\title{
Influence of the Population Density of Cities on Energy Consumption of Their Households
}

\author{
Pedro J. Zarco-Periñán *, Irene M. Zarco-Soto and Fco. Javier Zarco-Soto
}

check for updates

Citation: Zarco-Periñán, P.J.;

Zarco-Soto, I.M.; Zarco-Soto, F..J.

Influence of the Population Density of Cities on Energy Consumption of Their Households. Sustainability 2021, 13, 7542. https://doi.org/10.3390/ su13147542

Academic Editor: José Alberto Molina

Received: 31 May 2021

Accepted: 2 July 2021

Published: 6 July 2021

Publisher's Note: MDPI stays neutral with regard to jurisdictional claims in published maps and institutional affiliations.

Copyright: (c) 2021 by the authors. Licensee MDPI, Basel, Switzerland. This article is an open access article distributed under the terms and conditions of the Creative Commons Attribution (CC BY) license (https:/ / creativecommons.org/licenses/by/ $4.0 /)$.
Departamento de Ingeniería Eléctrica, Escuela Superior de Ingeniería, Universidad de Sevilla, Camino de los Descubrimientos, s/n, 41092 Sevilla, Spain; imzarco@outlook.com (I.M.Z.-S.); fjzarco@outlook.com (F.J.Z.-S.)

* Correspondence: pzarco@us.es

\begin{abstract}
: $36 \%$ of the energy consumed and $40 \%$ of emissions are due to buildings in the residential and tertiary sectors. These antecedents have forced governments to focus on saving energy and reducing emissions in this sector. To help government decision-making and facilitate energy planning for utilities, this work analyzes the energy consumption that occurs in city buildings. The information used to carry it out is publicly accessible. The study is carried out from the point of view of the population density of the cities, and these are analyzed individually. Furthermore, the area actually occupied by the city has been considered. The results are studied by inhabitant and household. The proposed method has been applied to the case of Spanish cities with more than 50,000 inhabitants. The results show that the higher the population density, the higher the energy consumption. This occurs both per inhabitant and per household. Furthermore, the consumption of electrical energy is inelastic, which is not the case with the consumption of thermal origin.
\end{abstract}

Keywords: population density; energy consumption; population behaviors; cities; buildings; Spain

\section{Introduction}

Energy is responsible for more than $80 \%$ of greenhouse gas (GHG) emissions, with transport corresponding to only a third [1]. Thirty six percent of the energy consumed and $40 \%$ of emissions are due to buildings in the residential and tertiary sectors [2]. In them, the usual form of energy consumption is through electricity and natural gas for thermal consumption [3].

Therefore, cities are the most important centers for the consumption of energy and the production of polluting emissions. Being aware of this, the European Union created the Covenant of Mayors. Subsequently, it changed its name to Climate \& Energy to integrate mayors from 8000 cities from 53 countries around the world. Among its objectives is to achieve access to affordable and sustainable energy for all citizens [4].

Currently, and because cities have been the main areas affected by the COVID-19 pandemic [5], the European Union has launched a EUR 750 billion recovery plan for COVID-19 [6] with six fields of action, one of which is construction and buildings [7].

For all the above, cities in general and their buildings in particular take a leading role for governments and utilities. In the case of the former, to establish laws that favor the reduction of consumption and emissions; in the latter, to plan the infrastructures that allow the growth of energy consumption, if possible, through renewable energy sources. Therefore, it is essential to know the relationship between energy and urbanization to achieve sustainable cities.

For this reason, this paper studies the energy consumption of buildings. All the buildings have been considered, and their consumption has been distributed among their inhabitants, including non-residential ones. This is so because non-residential buildings are used by the inhabitants of a city and exist in greater or lesser numbers depending on the population of it. 
The methodology used in the study, based on statistical analysis, is similar to others that, although classic, are still being used recently and use information from statistical databases [8-12] and on others that are based on the creation of synthetic populations [13]. Thus, the population of cities is represented in a simplified way from aggregated public data.

The main contributions of this paper are: analyze energy consumption of city buildings based on population density; study the behavior of the cities of a country separately, and not in an aggregate way; analyze the results by household and by inhabitant; and apply the method to the case of Spanish cities with more than 50,000 inhabitants. To the authors' knowledge, a similar investigation has not been carried out previously. With all this, it is intended that both utilities and governments have detailed knowledge of the behavior of cities based on their population density.

The article is structured as follows: Section 2 presents studies that relate energy in cities with the population density; Section 3 describes the proposed method, based on the use of public information; the application to the case of Spanish cities is presented in Section 4; the results, per inhabitant and household, are presented and discussed in Section 5; finally, Section 6 summarizes the findings of the study.

\section{Literature Review}

Utilities and governments are paying increasing attention to cities in general, and their buildings in particular, as focuses to reduce energy consumption. Therefore, this study investigates from the point of view of population density. Despite the importance that population density is acquiring in cities, this approach has been little analyzed [14]. Instead, the buildings have been analyzed individually: hotels [15], houses [16]; or the urban heat island generated [17]; or the relationship between transport and population density from the point of view of energy consumption [18].

Studies that analyze the population of cities have been carried out taking into account urbanization or population density. The most numerous are the first. They analyze the percentage of urban population with respect to the total national population. These give a general idea of the influence of migration from rural to urban areas. In addition, they usually refer to large areas, as is the case in the country-level analysis: Brazil [19], the USA [20], CIVETS countries, namely, Colombia, Indonesia, Vietnam, Egypt, Turkey, and South Africa [21], or 72 countries [22]. However, they do not provide information at the city level.

In general, the published works that analyze energy consumption focus on calculating the forecast of electricity demand at the country level, as is the case of Turkey [23], Spain [24], or Greece [25]; or at the level of the residential sector in some countries [26]. Studies that take natural gas into account usually also predict demand. This is the case of Pakistan [27], Bangladesh [28], or Bahrain, Saudi Arabia, Syria, and the United Arab Emirates [29]; or also at the residential level [30].

Using population density as a study variable, information can be obtained from a more specific area. This variable considers people by land area. In this way, it can be analyzed in more detail from a country [31] to a city [32] and is more appropriate for smaller areas. However, studies usually include the area occupied by the entire municipality and not just the area occupied by the populated area. Therefore, the population density that is calculated is that corresponding to the inhabitants who live in a certain city with respect to the entire area of the municipality, although a significant part of that area is neither inhabited nor has services for its inhabitants. However, from the authors' point of view, this is not valid for a detailed study of the influence of population density on certain magnitudes such as those analyzed in this study. On the contrary, the area considered must be that actually occupied by population.

The works that analyze the influence of population density do so considering the total energy. Therefore, they also include transport, so the influence of buildings is not 
specifically analyzed, despite being one of the main consumers of energy and producers of emissions [33].

Regarding the works that analyze energy consumption in buildings, they focus on a specific sector. Thus, in the electricity consumed in the residential sector, it increases when they do household income and number of rooms. In the study carried out in Malysia on a sample of 620 urban households, the average consumption was determined [34]. Depending on the urban density, the energy consumption increases up to a certain value, and from there it hardly has any influence. In the specific case of the study carried out in 29 provinces of China, this value is 808 inhabitants per square kilometer. In addition, other variables were used, such as economic development or urbanization. In the case of this last variable, the urbanization rate increased above $55.31 \%$; below this value, residential energy consumption decreased [35]. In the service sector, consumption per inhabitant is lower as density increases. This efficiency is justified by the higher factor productivity [36].

At the country level, in Kenya the possible drivers of energy consumption have been studied. Among them are population density and urbanization. In this case, while population density and urbanization reduce energy consumption, electricity consumption increases [37]. Something similar happens in China: as population density increases, energy consumption increases, while just the opposite occurs with urbanization [38]. However, in Canada the opposite is true. The electricity consumption of all sectors, except industrial, is analyzed and six predictors are used. Among them, population density is one of the determining factors. As a conclusion, it is obtained that when the population density is higher, the electricity consumption per capita is lower [39]. In addition, in a study of 93 countries, the results were found to be completely different from country to country [40].

Therefore, of the studies that analyze energy consumption, there are very few that relate energy consumption in buildings with population density. Not only that, but they also do not even consider a very important energy source, natural gas. Hence, the need to know more precisely the influence that population density has on energy consumption, in the case of this article, by applying the proposed method to the specific case of Spain.

\section{Materials and Methods}

The phases of the proposed method are as follows: first, the study area must be defined; second, the criteria for selecting the cities in that area are defined; third, cities must be classified according to density of inhabitants; and fourth, the consumption per inhabitant and per household in the buildings must be obtained.

The data used for the study should come from public databases and, whenever possible, should be of government origin. All this information must be properly processed to obtain the desired results. In this way, with the information on the energy consumed, it will be possible to implement specific measures that favor the reduction of consumption in each city and implement renewable energy sources that cover the growth in demand in each city and reduce their emissions. A methodological approach of the proposed method is shown in Figure 1.

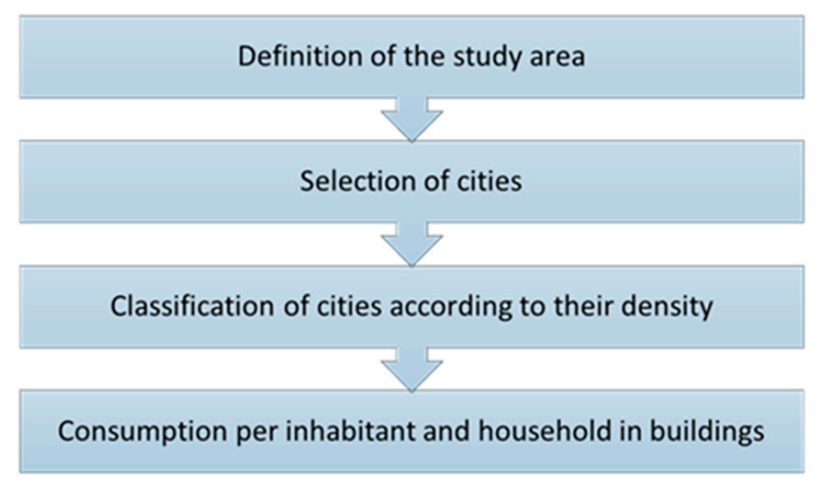

Figure 1. Methodological approach. 
Certain factors can influence energy consumption in cities. For example, the type of housing, the age of its construction, its orientation, the orographic characteristics of its surroundings, the climatic zone in which it is located, etc. However, their elimination is beyond the scope of this study. Therefore, the possible influence that they could have remains within the study.

\subsection{Classification of Cities by Population Density}

First, the area to study must be defined. Its size will depend on the scope of the study to be carried out. Next, the cities in that area must be selected. The selection will be made depending on the criteria of interest. These criteria can be the number of inhabitants, the energy consumed, the saturation of its infrastructure, its emissions, its growth rate, or any other that is of interest. From there, each city is represented by its population density and a segmentation can be defined.

To perform the analysis, the main statistical data of electric, thermal, and total energy consumptions for each group of cities are studied:

$$
\begin{gathered}
\text { Number of cities }: n_{i}=\sum_{j} 1 \\
\text { mean : } \bar{E}_{i}=\frac{\sum_{j} E_{i j}}{n_{i}} \\
\text { Standard deviation }: s_{i}=\sqrt{\frac{\sum_{i j}\left(E_{i j}-\bar{E}_{i}\right)^{2}}{\left(n_{i}-1\right)}}
\end{gathered}
$$

Median : Median $_{i}=\left[\frac{n_{i}+1}{2}\right]$ th term if the total number of the elements is an odd number, otherwise Median $n_{i}=\frac{\left(\frac{n_{i}}{2}\right) t h \text { term }+\left(\frac{n_{i}}{2}+1\right) t h \text { term }}{2}$

$$
\begin{aligned}
& \text { Maximum : } E_{i \max }=\max \left(E_{i j}\right) \\
& \text { Minimum : } E_{i \min }=\min \left(E_{i j}\right)
\end{aligned}
$$

where $n_{i}$ is the number of cities that belong to group $i ; \bar{E}_{i}$ is the mean energy consumed in group $i ; E_{i j}$ is the energy consumption of city $j$, which is located in group $i ; s_{i}$ is the standard deviation of the energy consumed in the cities of group $i$; the energy consumed will be thermal, electric or total depending on the case study; and cities consumptions should be listed in ascending order to calculate the median.

An index analogous to that defined in [41] is used to analyze the energy consumption of cities. The density variation index $(D V I)$ is defined as:

$$
D V I_{i}=\bar{E}_{i} / \bar{E}
$$

where $D V I_{i}$ is the index of the group of cities that have size $i, \bar{E}_{i}$ is the energy consumption mean value of group $i$ and $\bar{E}$ is the mean energy consumption of all cities (of all groups). With it, the consumption of the groups can be easily compared.

\subsection{Population Density of Cities}

To calculate the population density, it is necessary to identify the study area. One criterion is to consider the one that corresponds to the entire municipality of the city (this is the commonly used criterion). However, according to the authors, this is not the appropriate option. In certain cases, the city occupies the entire land area of the municipality; this usually happens in those highly populated cities with very little land area. However, usually the area of the municipality is greater than what the population occupies. Therefore, the whole area of the city municipality should not be considered, but only that which is actually populated. To do this, only the area occupied by buildings must 
be considered and not the rest. This surface can be continuous or discontinuous (depending on their housing scheme: single family houses or high-rise dwelling, city center of suburb).

This is the criterion that will be followed in the study: only the surface occupied by buildings will be considered, and this can be continuous or discontinuous. Therefore, the area considered is that occupied by continuous and discontinuous urban fabric [42].

\subsection{Electric and Thermal Energy Consumption}

To analyze energy consumption in cities, only that corresponding to buildings has been considered. That of industries has not been considered, nor that of means of transport. However, not only energy consumption in residential buildings has been considered, but also that of tertiary sector buildings. This is due to a double reason: on the one hand, the official data provided does not usually distinguish between whether the supply points correspond to residential, commercial, or administrative offices; and on the other, the rest of non-residential buildings in a city exist to serve its inhabitants, and their number is greater or lesser depending on the number of its inhabitants. For this reason, the study is carried out considering the energy consumption of all these buildings and is distributed among the inhabitants of each city.

Population and consumption data by city are used to calculate thermal and electrical consumption. In addition, they must be disaggregated from the information usually provided by public bodies. For electricity consumption, the classification of the Statistical Classification of Economic Activities in the European Community, commonly referred to as NACE (for the French term "nomenclature statistique des activités économiques dans la Communauté européenne") is used [43]. The following items have been considered: 36 to $39,53,60,61,72,84$ to 88 (exc. 85.5 and 85.6), 91, 99, 45 to $47,58.2,59,62$ to 71,73 to 75,77 to $82,85.5,85.6,90,92$ to 98 . It should be noted that electricity consumption does not only include that corresponding to lighting. It also covers the consumption of air conditioning in buildings and other uses that are made of electricity in them.

For thermal consumption, the information corresponding to supply points with a pressure equal to or less than $4 \mathrm{bar}$ and a consumption between 5000 and 50,000 kWh per year is used. These points are those that usually correspond to homes, stores, public administrations, and services.

\section{Application of the Method to the Case of Spain}

An example of application of the proposed method is presented in this section. As a study area, the whole of Spain is considered. In it, cities with more than 50,000 inhabitants have been selected. They represent more than $50 \%$ ( 24.5 million) of the 46.5 million inhabitants it has. The data used correspond to 2016. The results of the study will allow detailed knowledge of energy consumption, which will favor decision-making and the assessment of infrastructures that allow supplying energy demand and its growth.

\subsection{Classification of Spanish Cities}

To carry out the classification of cities according to their density, it is necessary to know the population [44] and the area of each one of them [45].

The number of cities that meet the criteria of having more than 50,000 inhabitants is 145 . From the public information available, their density, electricity and thermal consumption in the form of natural gas in their buildings and their emissions have been calculated.

Based on density, cities have been segmented into five groups. For this, the number of inhabitants per hectare has been calculated, being 1 hectare 10,000 square meter. Group 1 is made up of cities with a density lower than 100 inhabitants/hectare; Group 2, for those whose density is greater than or equal to 100 and less than 200; Group 3, for cities with a density greater than 200 and less than 300 inhabitants/hectare; Group 4 has a density between 300 and 400; and Group 5 is made up of cities with a density greater than 400 inhabitants/hectare. Table 1 shows the segmentation of the cities ordered alphabetically. 
Table 1. Classification of Spanish cities by density.

\begin{tabular}{|c|c|}
\hline Inhabitants/Hectare & Cities \\
\hline Group 1: density < 100 & $\begin{array}{l}\text { Albacete, Alcalá de Guadaíra, Alcoy/Alcoi, Alicante/Alacant, Aranjuez, Arganda del Rey, } \\
\text { Arona, Ávila, Badajoz, Benalmádena, Benidorm, Boadilla del Monte, Cáceres, Cartagena, } \\
\text { Castellón de la Plana, Chiclana de la Frontera, Ciudad Real, Collado Villalba, Córdoba, } \\
\text { Elche/Elx, Elda, Estepona, Ferrol, Jerez de la Frontera, Linares, Línea de la Concepción (La), } \\
\text { Lorca, Lugo, Marbella, Mérida, Mijas, Murcia, Orihuela, Ourense, Paterna, Ponferrada, } \\
\text { Pontevedra, Pozuelo de Alarcón, Puerto de Santa María, Rivas-Vaciamadrid, Rozas de } \\
\text { Madrid (Las), Rubí, Sagunto/Sagunt, San Cristóbal de la Laguna, San Sebastián de los } \\
\text { Reyes, San Vicente del Raspeig, Sanlúcar de Barrameda, Sant Cugat del Vallès, Santiago de } \\
\text { Compostela, Talavera de la Reina, Toledo, Torrelavega, Torrevieja, Utrera, Vélez-Málaga, } \\
\text { Vigo, Vila-Real }\end{array}$ \\
\hline Group 2: $100 \leq$ density $<200$ & $\begin{array}{l}\text { Alcobendas, Algeciras, Almería, Arrecife, Avilés, Burgos, Castelldefels, Cerdanyola del } \\
\text { Vallès, Coslada, Cuenca, Dos Hermanas, Ejido (El), Fuengirola, Gandía, Getxo, Gijón, } \\
\text { Girona, Granada, Granollers, Guadalajara, Huesca, Irún, Jaén, Las Palmas, León, Lleida, } \\
\text { Logroño, Majadahonda, Málaga, Manresa, Molina de Segura, Motril, Oviedo, Palencia, } \\
\text { Palma de Mallorca, Pinto, Reus, Roquetas de Mar, Salamanca, San Bartolomé de Tirajana, } \\
\text { San Sebastián/Donostia, Santa Cruz de Tenerife, Santa Lucía de Tirajana, Santander, } \\
\text { Segovia, Siero, Tarragona, Telde, Terrassa, Torremolinos, Valdemoro, Valladolid, Vilanova i } \\
\text { la Geltrú, Vitoria/Gasteiz, Zamora, Zaragoza }\end{array}$ \\
\hline Group 3: $200 \leq$ density $<300$ & $\begin{array}{l}\text { A Coruña, Alcalá de Henares, Alcorcón, Barakaldo, Ceuta, Getafe, Leganés, Madrid, } \\
\text { Mataró, Melilla, Mollet del Vallès, Móstoles, Pamplona/Iruña, Sabadell, San Fernando, Sant } \\
\text { Boi de Llobregat, Sevilla, Valencia, Viladecans }\end{array}$ \\
\hline Group 4: $300 \leq$ density $<400$ & $\begin{array}{l}\text { Badalona, Barcelona, Bilbao, Cádiz, Fuenlabrada, Huelva, Parla, Prat de Llobregat (El), } \\
\text { Torrejón de Ardoz }\end{array}$ \\
\hline Group 5: $400 \leq$ density & Cornellà de Llobregat, L'Hospitalet de Llobregat, Santa Coloma de Gramenet, Torrent \\
\hline
\end{tabular}

Although the influence of external factors has not been eliminated, it must be mentioned that the climate is one of those that may be of greater importance. That is why, to have a vision of the types of climates in which cities are located, Figure 2 shows the types of climates in Spain and the number of cities studied that are in each of them [41].

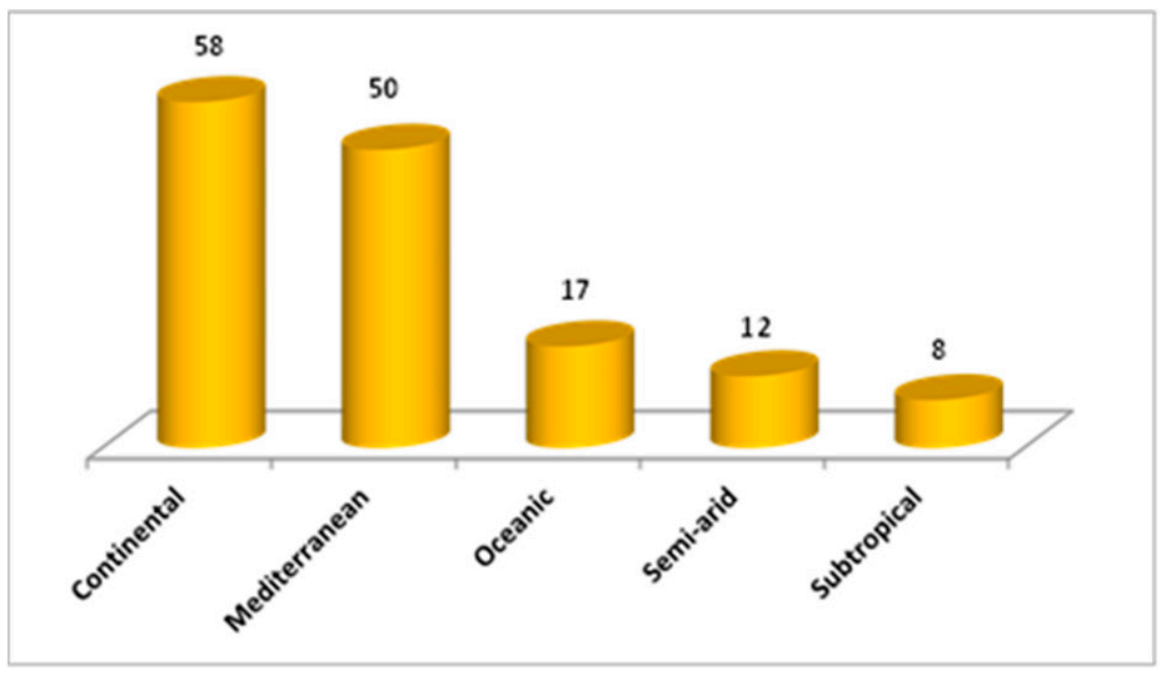

Figure 2. Number of cities by type of climate of Spain.

\subsection{Thermal and Electric Energy Consumption}

To obtain the consumption of thermal and electrical energy, information from the Ministry of Economic Affairs and Digital Transformation and the Ministry for Ecological Transition and Demographic Challenge has been used: Spanish National Statistics Insti- 
tute [46], National Commission on Markets and Competition [47], Secretary of State for Energy [48].

\section{Results and Discussion}

\subsection{Sample of Study}

The energy consumption in the buildings of the 145 Spanish cities with more than 50,000 inhabitants have been studied. The buildings are those corresponding to households, government agencies, and tertiary sectors. Consumption is that usually used in buildings: thermal in the form of natural gas and electricity. The data used are public and from official sources, although properly processed. The cities have been segmented into five groups according to Table 1 .

Figure 3 presents the number of cities in each group. The most numerous groups are the two with the lowest population density. Each of them represents almost $40 \%$ of cities. The rest of the groups only represent $22 \%$ and as the density increases, the number of cities decreases. Thus, the group of cities with the highest density barely represents $3 \%$. However, of the number of inhabitants, Group 2 is the largest, with $32 \%$ of the total. Groups 3 and 1 follow with more than $25 \%$. The one with the lowest number of inhabitants is Group 5, with only $2 \%$ (Figure 4 ).

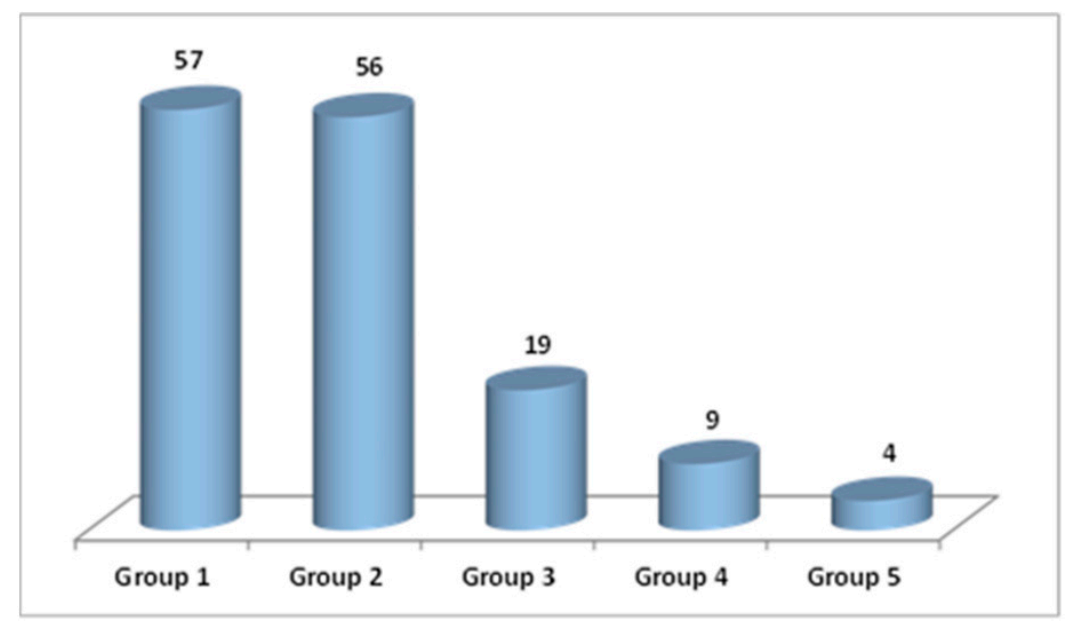

Figure 3. Number of cities of each group.

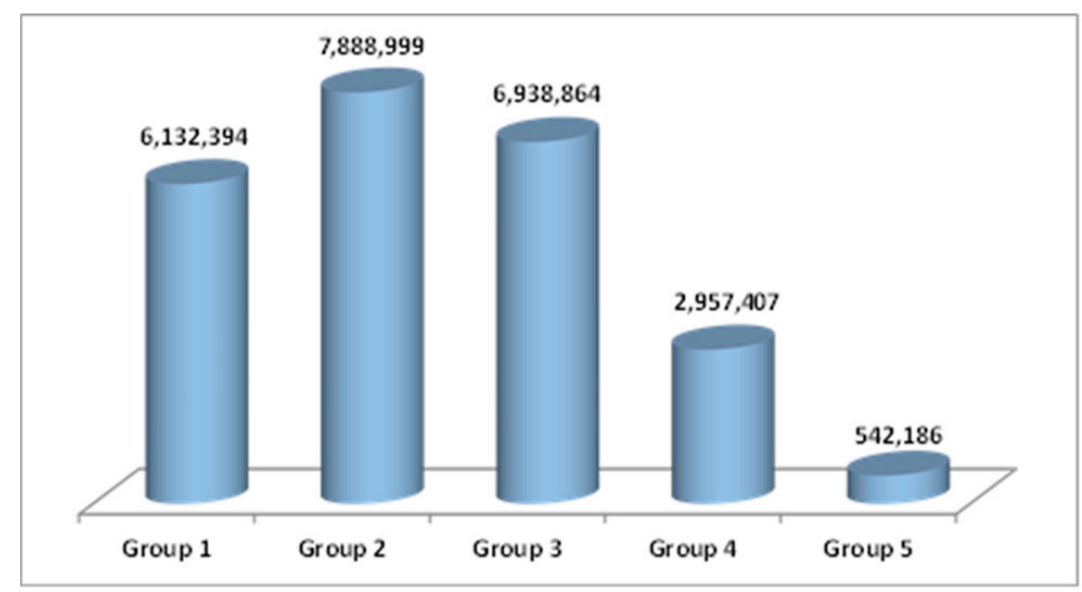

Figure 4. Population of each group of cities.

Table 2 shows the main statistical data of the households and population of each group. The first column shows each of the groups into which the analysis has been divided, and each of its rows contains its statistical data. The conclusions are similar to those indicated. 
Table 2. Statistical data by population and household of each group of cities.

\begin{tabular}{|c|c|c|c|c|c|c|c|c|c|c|c|c|}
\hline \multirow[b]{2}{*}{$\begin{array}{c}\text { Population } \\
\text { Density }\end{array}$} & \multicolumn{6}{|c|}{ POPULATION } & \multicolumn{6}{|c|}{ NUMBEROF HOUSEHOLDS } \\
\hline & Total & Mean & Std. Dev. & Median & Maximum & Minimum & Total & Mean & Std. Dev. & Median & Maximum & Minimum \\
\hline Group 1 & $6,132,394$ & 107,586 & 79,857 & 79,878 & 443,243 & 50,334 & $2,280,611$ & 40,011 & 29,113 & 29,727 & 154,421 & 15,434 \\
\hline Group 2 & $7,888,999$ & 140,875 & 123,196 & 90,730 & 664,938 & 50,442 & $3,060,916$ & 54,659 & 48,525 & 33,872 & 269,347 & 18,160 \\
\hline Group 3 & $6,938,864$ & 365,203 & 710,045 & 178,288 & $3,182,981$ & 51,128 & $2,684,033$ & 141,265 & 282,318 & 67,113 & $1,262,282$ & 18,967 \\
\hline Group 4 & $2,957,407$ & 328,601 & 491,187 & 145,115 & $1,620,809$ & 63,897 & $1,167,260$ & 129,696 & 204,159 & 54,952 & 666,143 & 23,831 \\
\hline Group 5 & 542,186 & 135,547 & 82,802 & 102,104 & 257,349 & 80,630 & 201,649 & 50,412 & 31,580 & 37,685 & 97,044 & 29,235 \\
\hline
\end{tabular}

\subsection{Total Energy Consumption}

Table 3 shows, in each of its rows, the statistical data of the total consumption of each group, in MWh per year. The highest consumptions are produced in Groups 2 and 3, with almost identical consumptions, even though Group 2 has almost 15\% more inhabitants. They are followed by Group 1 with a 36\% lower consumption, although its number of inhabitants is only $11 \%$ lower. Group 5 is the one with the lowest consumption.

From the point of view of electricity consumption, the behavior is similar. However, the consumption of Group 2 is $12 \%$ higher than that of Group 3, even though the total consumption of both groups was almost identical. Regarding thermal consumption, Groups 2 and 3 have a behavior contrary to that presented in electricity consumption: Group 3 is the one with the highest consumption, followed by Group 2. The rest of the groups follow a similar behavior.

Graphically, Figure 5 presents the total, thermal and electrical consumption of each group in GWh per year. The consumptions that a group of average values would present are also shown. It can be observed that, at the level of total consumption, Groups 2 and 3 have higher consumption than the average value, while Groups 4 and 5 have lower consumption; Group 1 has a total consumption almost identical to the average value. Therefore, when analyzing this figure and relating it to Figure 3; Figure 4 of the number of cities and inhabitants per group respectively, it is not possible to draw a conclusion about the trend that exists in the global consumption of each group. Global consumption does not follow a trend proportional to the number of cities per group or of inhabitants. Regarding electrical and thermal consumption, the behavior is similar to that described, except in Group 1, which in the case of electrical consumption is above the average value and in the case of thermal, below.

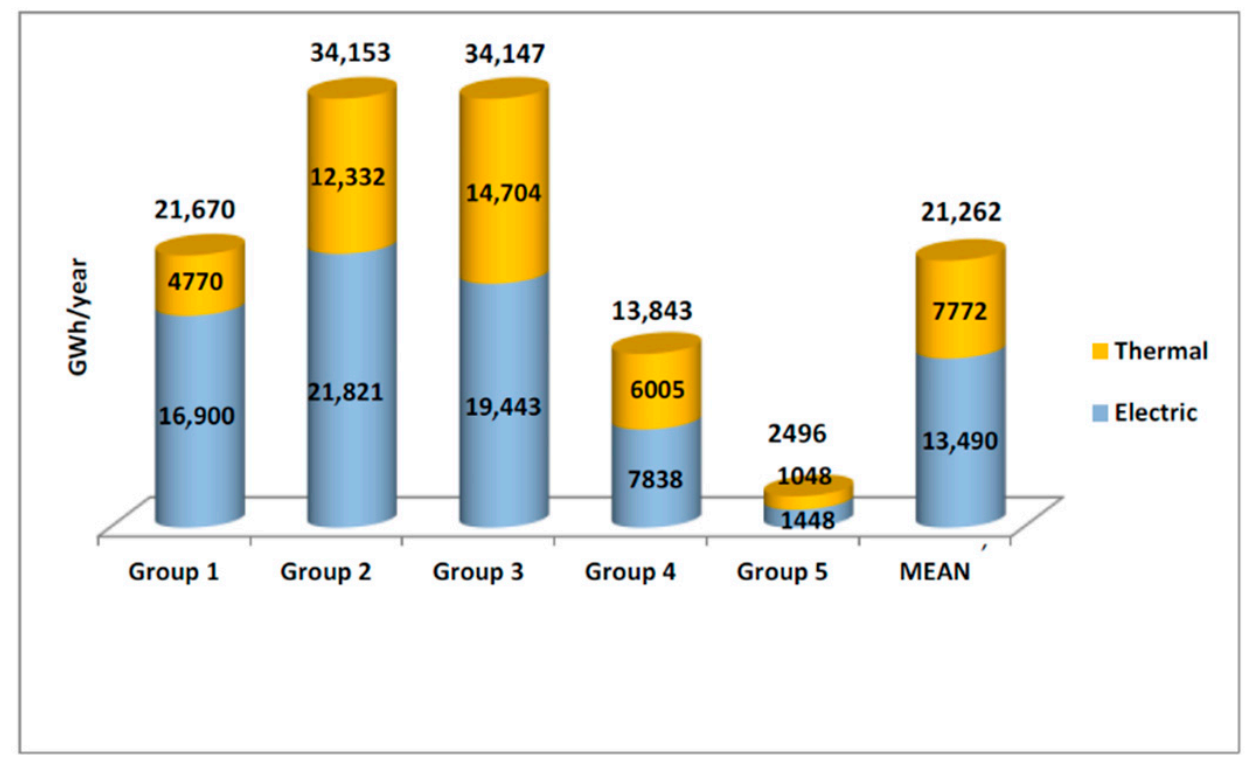

Figure 5. Thermal, electric, and total mean energy consumption of each group of cities. 
Table 3. Statistical data of consumption of each group of cities.

\begin{tabular}{|c|c|c|c|c|c|c|c|c|c|c|c|c|c|c|c|c|c|c|}
\hline \multirow[b]{2}{*}{$\begin{array}{c}\text { Population } \\
\text { Density }\end{array}$} & \multirow[b]{2}{*}{ Total } & \multicolumn{5}{|c|}{ TOTAL (MWh/year) } & \multicolumn{7}{|c|}{ THERMAL (MWh/year) } & \multicolumn{5}{|c|}{ ELECTRIC (MWh/year) } \\
\hline & & Mean & $\begin{array}{l}\text { Std. } \\
\text { Dev. }\end{array}$ & Median & Max. & Min. & Total & Mean & $\begin{array}{l}\text { Std. } \\
\text { Dev. }\end{array}$ & Median & Max. & Min. & Total & Mean & $\begin{array}{l}\text { Std. } \\
\text { Dev. }\end{array}$ & Median & Max. & Min. \\
\hline Group 1 & $21,669,891$ & 380,174 & 260,575 & 303,694 & $1,516,830$ & 140,786 & $4,769,859$ & 83,682 & 72,436 & 56,765 & 267,920 & 0.00 & $16,900,032$ & 296,492 & 229,752 & 210,365 & $1,340,879$ & 120,861 \\
\hline Group 3 & $34,147,099$ & $1,797,216$ & $4,073,759$ & 972,005 & $18,400,465$ & 143,830 & $14,703,803$ & 773,884 & $1,997,447$ & 268,310 & $8,969,965$ & 0.00 & $19,443,297$ & $1,023,331$ & $2,099,678$ & 528,230 & $9,430,500$ & 135,908 \\
\hline Group 4 & $13,842,679$ & $1,538,075$ & $2,366,828$ & 740,029 & $7,756,365$ & 286,388 & $6,004,988$ & 667,221 & $1,065,972$ & 360,754 & $3,447,946$ & 20,960 & $7,837,691$ & 870,855 & $1,304,278$ & 379,275 & $4,308,420$ & 169,850 \\
\hline Group 5 & $2,495,895$ & 623,974 & 420,414 & 488,615 & $1,231,541$ & 287,123 & $1,047,692$ & 261,923 & 205,067 & 217,205 & 547,458 & 65,824 & $1,448,203$ & 362,051 & 218,586 & 271,411 & 684,083 & 221,299 \\
\hline
\end{tabular}




\subsection{Energy Consumptions per Household}

Table 4 and Figure 6 show the main statistical data and the average values of energy consumption per household, respectively. Total energy consumption increases as density increases, except between the two highest density groups, among which there is a small decrease of $2 \%$. The group with the lowest density, Group 1, is the only one that has a lower value than the mean value of all the groups. While the group with the highest consumption presents a value $13 \%$ higher than the average value, the lowest is $8 \%$ below. In addition, the differences in consumption between groups are similar, none of them being much more pronounced than the rest.

Table 4. Statistical data of energy consumptions per household of each group of cities.

\begin{tabular}{|c|c|c|c|c|c|c|c|c|c|c|c|c|c|c|c|}
\hline \multirow[b]{2}{*}{$\begin{array}{l}\text { Population } \\
\text { Density }\end{array}$} & \multicolumn{5}{|c|}{ TOTAL (MWh/year) } & \multicolumn{5}{|c|}{ THERMAL (MWh/year) } & \multicolumn{5}{|c|}{ ELECTRIC (MWh/year) } \\
\hline & Mean & $\begin{array}{l}\text { Std. } \\
\text { Dev. }\end{array}$ & Median & Max. & Min. & Mean & $\begin{array}{l}\text { Std. } \\
\text { Dev. }\end{array}$ & Median & Max. & Min. & Mean & $\begin{array}{l}\text { Std. } \\
\text { Dev. }\end{array}$ & Median & Max. & Min. \\
\hline Group 1 & 9.90 & 3.45 & 8.46 & 18.79 & 5.99 & 2.59 & 2.71 & 1.32 & 9.16 & 0.00 & 7.31 & 1.08 & 7.16 & 9.63 & 5.68 \\
\hline Group 2 & 11.17 & 3.14 & 11.21 & 18.44 & 6.04 & 4.01 & 2.87 & 4.54 & 8.99 & 0.00 & 7.16 & 1.14 & 7.03 & 9.64 & 5.30 \\
\hline Group 3 & 11.88 & 3.67 & 12.83 & 16.07 & 5.66 & 4.84 & 2.97 & 5.70 & 8.63 & 0.00 & 7.03 & 0.80 & 7.12 & 8.24 & 5.66 \\
\hline Group 4 & 12.31 & 4.13 & 12.63 & 17.28 & 6.26 & 5.17 & 3.03 & 5.62 & 8.43 & 0.46 & 7.15 & 1.24 & 7.02 & 8.86 & 5.74 \\
\hline Group 5 & 11.97 & 1.55 & 12.54 & 13.11 & 9.69 & 4.80 & 1.72 & 5.57 & 5.83 & 2.22 & 7.17 & 0.25 & 7.14 & 7.47 & 6.94 \\
\hline
\end{tabular}

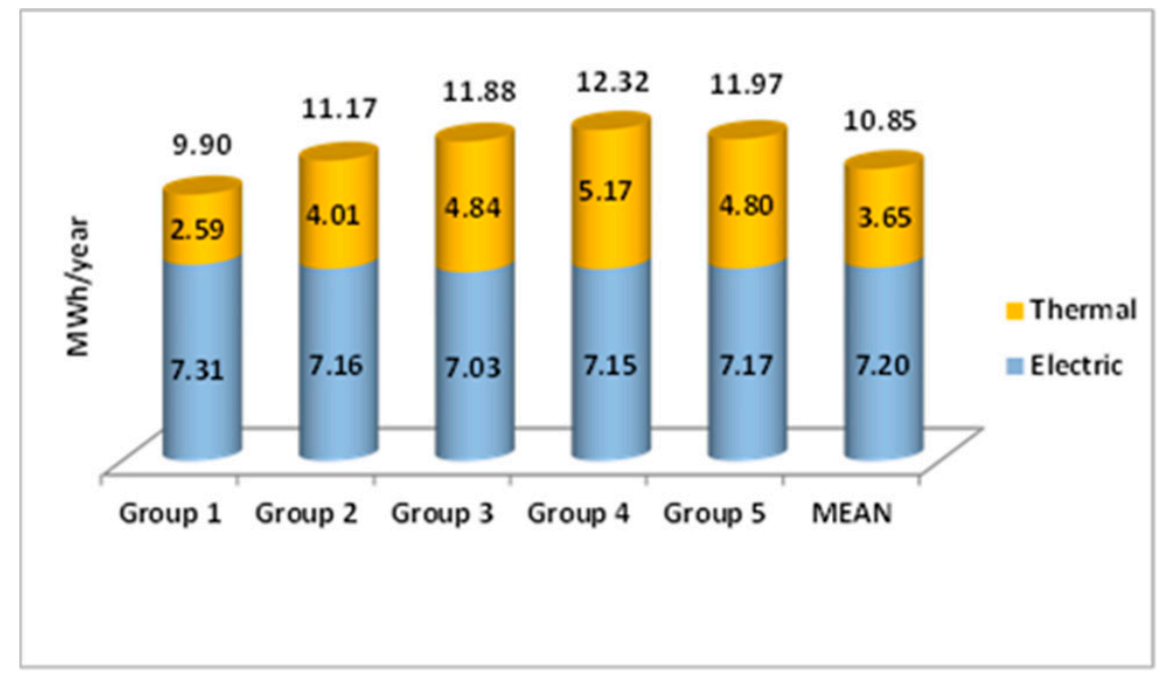

Figure 6. Thermal, electric, and total mean energy consumption per household of each group of cities.

Thermal consumption follows a similar behavior, although not identical. The main difference is that the second group with the highest consumption is not the densest cities, Group 5, but Group 3, although with similar values between them. The group with the highest consumption is $42 \%$ higher than the average, while the group with the lowest thermal consumption is $30 \%$ lower. Therefore, the differences between the extreme groups are much more pronounced than in the case of the comparison in total consumption. In fact, among the less dense groups the difference that exists is almost $40 \%$. Only Group 1 has a lower value than the value of the mean group.

Regarding electricity consumption, it is the least dense group that has the highest consumption, and Group 3 that has the lowest, with the consumption of the rest of the groups being almost identical. However, the difference between the maximum and minimum consumption is only $3 \%$. Therefore, the electrical consumption presents an inelastic behavior. In addition, now the opposite occurs, and only Group 1 is the one with a higher-than-average consumption.

The DVI index defined in Equation (7) has been used to easily analyze the variations in consumption between groups. Figure 7 shows the index for the three types of consumption. Total consumption increases as population density increases, except in the group of most 
populated cities, in which it decreases slightly. Furthermore, this increase is relatively mild. In the case of thermal consumption, the behavior of consumption is similar to the total. However, the differences are much more pronounced, reaching $70 \%$ between the extremes. Regarding electricity consumption, it is similar in all groups, with a minimal difference between all of them.

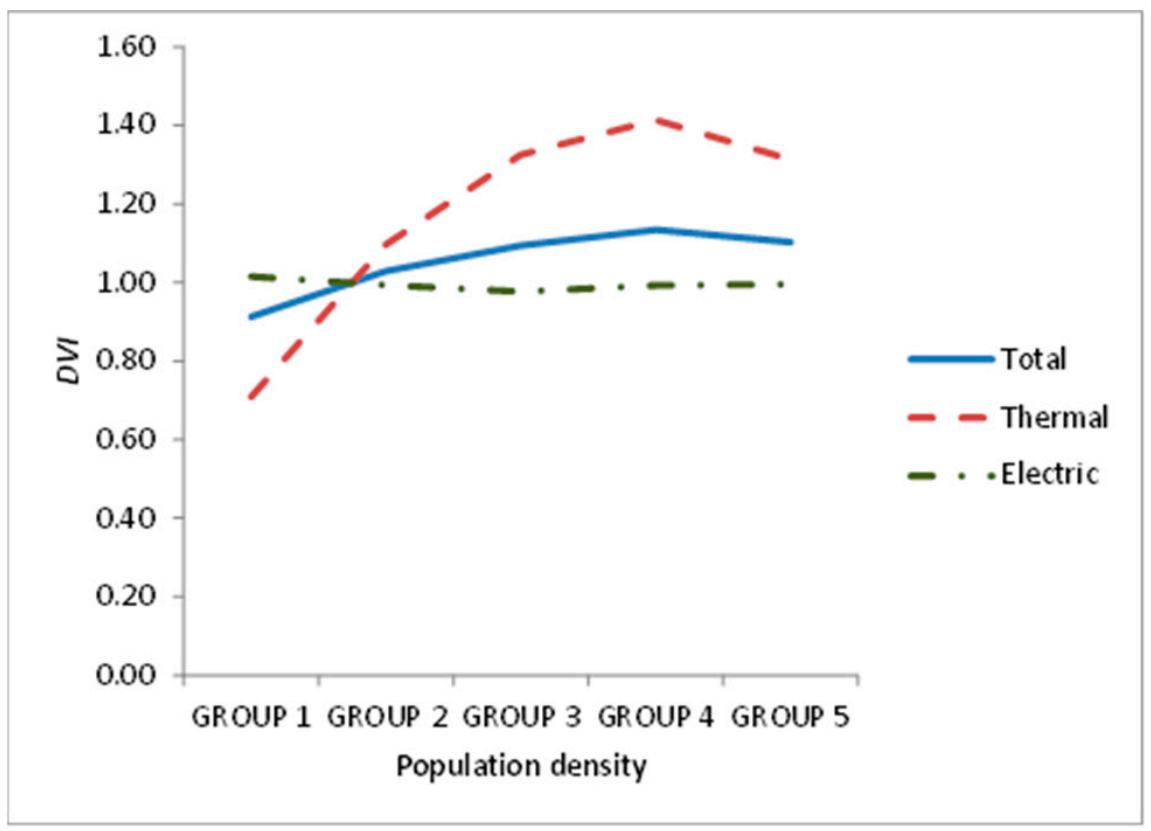

Figure 7. Variation of the DVI index for energy consumptions per household of each group of cities.

As conclusion: the higher the population density in the cities, the higher the consumption, except in the four cities with the highest density, in which it decreases slightly; and the electrical consumption is almost inelastic, whereas the thermal one is not. Furthermore, although the increase in total consumption between groups is approximately homogeneous, the growth in thermal consumption is not. In fact, a very significant increase occurs among the groups with the lowest density.

\subsection{Energy Consumptions per Inhabitant}

Table 5 shows the statistical data of the consumption per inhabitant and Figure 8 the mean values of each group and the mean consumption of all the groups, in MWh per year. As density increases, per capita consumption increases, up to a density of between 300 and 400 inhabitants/hectare, Group 4. The four cities that make up the group with the highest density, Group 5, have consumption identical to Group 3. The greatest difference in consumption between groups occurs between the one corresponding to the lowest density group, Group 1, and the next, reaching 15\%. Among the rest of the groups, the difference in consumption only oscillates $5 \%$. The only group with a value lower than the mean value is Group 1.

Thermal consumption is similar to total consumption. Group 4 is the one with the highest consumption, with Group 3 being the next. However, the difference between the three densest groups is barely $5 \%$. The one with the lowest consumption is Group 1, which is also the only one that has a value lower than the average of the groups. In this case, the differences in consumption between groups are more pronounced. Thus, the difference between the extreme groups reaches over $70 \%$. The greatest difference occurs between Groups 1 and 2, being greater than $45 \%$. However, the difference from the rest of the groups is just over $20 \%$. 
Table 5. Statistical data of energy consumptions per inhabitant of each group of cities.

\begin{tabular}{cccccccccccccccc}
\hline & \multicolumn{4}{c}{ TOTAL (MWh/year) } & \multicolumn{4}{c}{ THERMAL (MWh/year) } & \multicolumn{4}{c}{ ELECTRIC (MWh/year) } \\
\hline $\begin{array}{c}\text { Population } \\
\text { Density }\end{array}$ & Mean & $\begin{array}{c}\text { Std. } \\
\text { Dev. }\end{array}$ & Median & Max. & Min. & Mean & $\begin{array}{l}\text { Std. } \\
\text { Dev. }\end{array}$ & Median & Max. & Min. & Mean & $\begin{array}{c}\text { Std. } \\
\text { Dev. }\end{array}$ & Median & Max. & Min. \\
\hline Group 1 & 3.69 & 1.05 & 3.33 & 5.78 & 2.40 & 0.94 & 0.91 & 0.56 & 2.82 & 0.00 & 2.75 & 0.32 & 2.74 & 3.57 & 2.25 \\
Group 2 & 4.33 & 1.19 & 4.53 & 6.47 & 2.40 & 1.57 & 1.11 & 1.93 & 3.76 & 0.00 & 2.76 & 0.34 & 2.71 & 3.86 & 2.25 \\
Group 3 & 4.48 & 1.45 & 4.79 & 6.35 & 1.67 & 1.84 & 1.12 & 2.13 & 3.45 & 0.00 & 2.64 & 0.38 & 2.66 & 2.96 & 1.67 \\
Group 4 & 4.56 & 1.27 & 4.79 & 6.35 & 2.43 & 1.90 & 1.07 & 2.13 & 3.45 & 0.18 & 2.66 & 0.23 & 2.66 & 2.96 & 2.25 \\
Group 5 & 4.48 & 1.07 & 4.79 & 5.78 & 2.62 & 1.80 & 0.92 & 2.13 & 2.82 & 0.19 & 2.68 & 0.18 & 2.66 & 2.96 & 2.43 \\
\hline
\end{tabular}

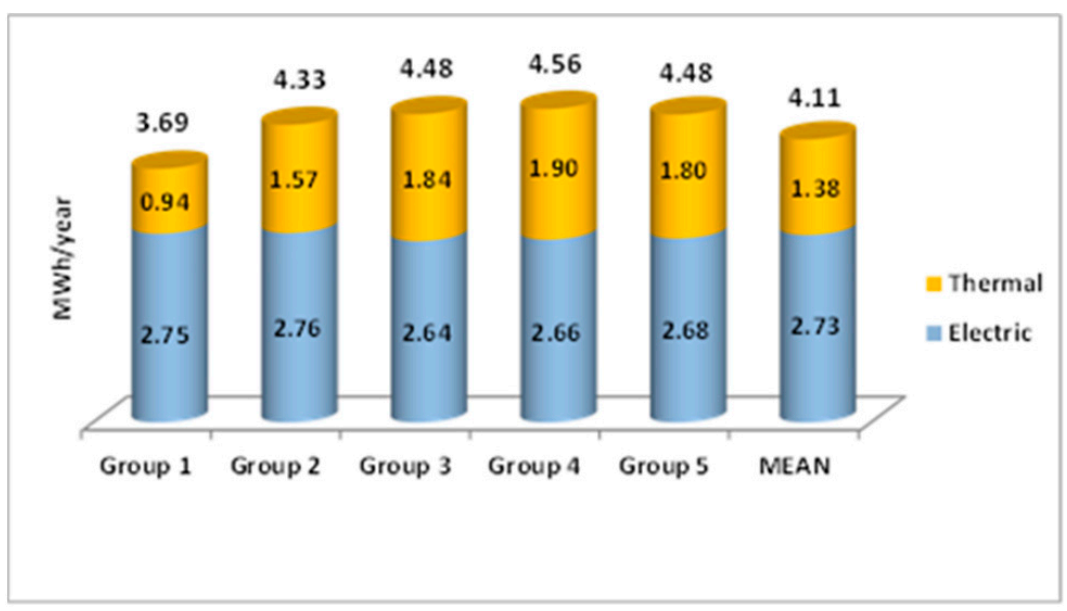

Figure 8. Thermal, electric, and total mean energy consumption per inhabitant of each group of cities.

Regarding electricity consumption, this is similar in all groups, oscillating only $4 \%$ among all. However, here it is Groups 1 and 2 that have a higher consumption than the mean, although this is minimal.

The variation of the DVI index for all consumptions per inhabitant is shown in Figure 9. Total consumption increases with increasing population density, except in the group of four cities with the highest density. Furthermore, except in Group 1, the variation that occurs among the other groups is $5 \%$. However, from Group 1 to 2 there is a difference of $15 \%$.

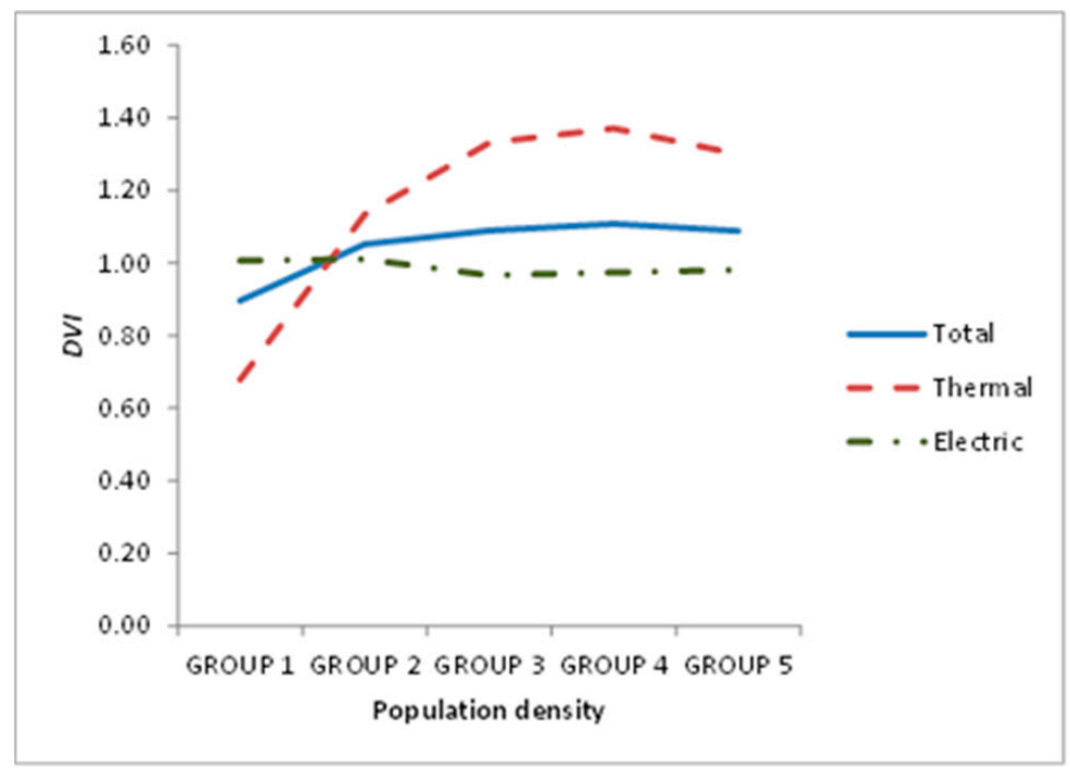

Figure 9. Variation of the DVI index for energy consumptions per inhabitant of each group of cities. 
Regarding thermal consumption, the behavior is similar, but here the differences are again more pronounced. These differences are greater between Group 1 and 2 (reaching 45\%), and between 2 and 3 (reaching 20\%). Regarding electricity consumption, the behavior is almost identical in all groups. There is only a $3 \%$ variation between all of them.

The conclusions are similar to those obtained when studying households: the higher the population density, the higher the consumption, except in the cities with the highest density, where there is a slight decrease; in addition, the thermal consumption is elastic, with the electrical being practically inelastic. In addition, the differences between groups are more pronounced than those presented in consumption per household, mainly in relation to thermal consumption.

\section{Conclusions}

Eighty percent of GHG emissions correspond to $\mathrm{CO}_{2} .40 \%$ of the emissions are due to buildings in the residential and tertiary sectors. In addition, they consume $36 \%$ of the energy. Against this background, governments consider cities in general, and buildings in particular, priority centers for reducing energy consumption and emissions. Considering also that the COVID-19 pandemic has mainly affected cities, the concern of governments is evident. For all this, Covenant of Mayors and the COVID-19 recovery plan have been created.

To help governments make decisions and utilities to plan their infrastructures correctly, this paper has analyzed the energy consumption of buildings in cities. Electricity and thermal consumption in the form of natural gas have been considered. These are the forms of energy commonly consumed in buildings. The study has been carried out from the point of view of the population density of the cities. For this, the area that the city actually occupies has been considered, and not the area covered by the municipality, which always has large uninhabited areas. In addition, the energy consumption of all buildings has been considered, both for residential and tertiary use. The results have been analyzed per inhabitant and per household. Therefore, the consumption of non-residential buildings has been distributed among the inhabitants and households of the city. This has been done because cities have a greater or lesser number of tertiary sector buildings to serve their inhabitants, and they exist insofar as they are necessary for them. For ease of analysis, an index has been introduced. Information of public access has been used for the study. The case of the 145 Spanish cities with more than 50,000 inhabitants has been presented as an application of the proposed method.

The results of the total consumption of the groups do not show a relationship with respect to the number of cities in each group or with the number of inhabitants of each one of them.

The findings obtained on consumption per household show that the higher the population density in the city, the higher the consumption. However, there is an exception in the four cities with the highest density, in which consumption decreases slightly compared to the previous group. Furthermore, while total consumption has an approximately homogeneous growth among the different groups, in the case of thermal consumption such growth is very marked. Regarding electricity consumption, it hardly changes as a consequence of the variation in the density of cities. Thus, electrical consumption is almost inelastic, while thermal is quite elastic.

Regarding consumption per inhabitant, the conclusions are similar to those obtained per household. Thus, the higher the population density in the city, the higher the consumption, except in the four densest cities. The fact that electricity consumption is inelastic is also represented. However, thermal consumption is elastic and even with variations between groups much more pronounced than in the case of consumption per household.

These conclusions will allow utilities and governments to have a detailed understanding of the behavior of energy consumption in cities as a function of their density. In this way, utilities will be able to adequately plan their infrastructures and governments will issue laws that help optimize energy use in buildings. 
Author Contributions: Conceptualization, I.M.Z.-S. and P.J.Z.-P.; methodology, I.M.Z.-S. and P.J.Z.-P.; validation, I.M.Z.-S., F.J.Z.-S. and P.J.Z.-P.; formal analysis, I.M.Z.-S., F.J.Z.-S. and P.J.Z.-P.; investigation, I.M.Z.-S. and P.J.Z.-P.; data curation, I.M.Z.-S. and F.J.Z.-S.; writing-original draft preparation, P.J.Z.-P.; writing一review and editing, I.M.Z.-S., F.J.Z.-S. and P.J.Z.-P.; visualization, I.M.Z.-S.; supervision, P.J.Z.-P.; project administration, P.J.Z.-P.; funding acquisition, P.J.Z.-P. All authors have read and agreed to the published version of the manuscript.

Funding: This research received no external funding.

Institutional Review Board Statement: Not applicable.

Informed Consent statement: Not applicable.

Data Availability Statement: Not applicable.

Acknowledgments: The authors would like to thank eCitySevilla project for providing facilities to conduct the research.

Conflicts of Interest: The authors declare no conflict of interest.

\section{References}

1. European Parliament News. Available online: https://www.europarl.europa.eu/news/en/headlines/society/20180301STO989 28/greenhouse-gas-emissions-bycountry-and-sector-infographic (accessed on 12 October 2020).

2. International Energy Agency; United Nations Environment Programme. 2018 Global Status Report: Towards a Zero-Emission, Efficient and Resilient Buildings and Construction Sector. 2018. Available online: https://wedocs.unep.org/20.500.11822/27140 (accessed on 12 October 2020).

3. Shahrokni, H.; Levihn, F.; Brandt, N. Big meter data analysis of the energy efficiency potential in Stockholm's building stock. Energy Build. 2014, 78, 153-164. [CrossRef]

4. Energy Cities. Covenant of Mayors for Climate \& Energy. Available online: https://energy-cities.eu/project/covenant-of-mayorsfor-climate-energy /\#: \{\}:text=The \%20Covenant $\% 20$ of $\% 20$ Mayors\%20gathers, and $\% 20$ affordable $\% 20$ energy $\% 20$ to $\% 20$ all (accessed on 13 May 2020).

5. Department of Economic and Social Affairs. Make Cities and Human Settlements Inclusive, Safe, Resilient and Sustainable. Available online: https:/ /sdgs.un.org/goals/goal11 (accessed on 14 September 2020).

6. European Parliament News. Green Deal: Key to a Climate-Neutral and Sustainable EU. Available online: https://www.europarl. europa.eu/news/en/headlines/society /20200618STO81513/green-deal-key-to-a-climate-neutral-and-sustainable-eu (accessed on 25 July 2020).

7. COM 98 Final. A New Circular Economy Action Plan for a Cleaner and More Competitive Europe; European Commission: Brussels, Belgium, 2020.

8. Jiang, L.; Xing, R.; Chen, X.; Xue, B. A survey-based investigation of greenhouse gas and pollutant emissions from household energy consumption in the Qinghai-Tibet Plateau of China. Energy Build. 2021, 235, 110753. [CrossRef]

9. Zarco-Soto, I.M.; Zarco-Periñán, P.J.; Sánchez-Durán, R. Influence of cities population size on their energy consumption and $\mathrm{CO}_{2}$ emissions: The case of Spain. Environ. Sci. Pollut. Res. 2021, 28, 28146-28167. [CrossRef]

10. Huo, T.; Ren, H.; Cai, W. Estimating urban residential building-related energy consumption and energy intensity in China based on improved building stock turnover model. Sci. Total. Environ. 2019, 650, 427-437. [CrossRef]

11. Urquizo, J.; Calderón, C.; James, P. Metrics of urban morphology and their impact on energy consumption: A case study in the United Kingdom. Energy Res. Soc. Sci. 2017, 32, 193-206. [CrossRef]

12. Bart, I.L. Urban sprawl and climate change: A statistical exploration of cause and effect, with policy options for the EU. Land Use Policy 2010, 27, 283-292. [CrossRef]

13. Nägeli, C.; Camarasa, C.; Jakob, M.; Catenazzi, G.; Ostermeyer, Y. Synthetic building stocks as a way to assess the energy demand and greenhouse gas emissions of national building stocks. Energy Build. 2018, 173, 443-460. [CrossRef]

14. Salim, R.A.; Shafiei, S. Urbanization and renewable and non-renewable energy consumption in OECD countries: An empirical analysis. Econ. Model. 2014, 38, 581-591. [CrossRef]

15. Dibene-Arriola, L.; Carrillo-González, F.; Quijas, S.; Rodríguez-Uribe, M. Energy Efficiency Indicators for Hotel Buildings. Sustainability 2021, 13, 1754. [CrossRef]

16. Todeschi, V.; Boghetti, R.; Kämpf, J.; Mutani, G. Evaluation of Urban-Scale Building Energy-Use Models and Tools-Application for the City of Fribourg, Switzerland. Sustainability 2021, 13, 1595. [CrossRef]

17. Tian, L.; Li, Y.; Lu, J.; Wang, J. Review on Urban Heat Island in China: Methods, Its Impact on Buildings Energy Demand and Mitigation Strategies. Sustainability 2021, 13, 762. [CrossRef]

18. Dingil, A.E.; Schweizer, J.; Rupi, F.; Stasiskiene, Z. Updated Models of Passenger Transport Related Energy Consumption of Urban Areas. Sustainability 2019, 11, 4060. [CrossRef]

19. Adebayo, T.; Awosusi, A.; Odugbesan, J.; Akinsola, G.; Wong, W.-K.; Rjoub, H. Sustainability of Energy-Induced Growth Nexus in Brazil: Do Carbon Emissions and Urbanization Matter? Sustainability 2021, 13, 4371. [CrossRef] 
20. Dogan, E.; Turkekul, B. $\mathrm{CO}_{2}$ emissions, real output, energy consumption, trade, urbanization and financial development: Testing the EKC hypothesis for the USA. Environ. Sci. Pollut. Res. 2016, 23, 1203-1213. [CrossRef] [PubMed]

21. Nathaniel, S.; Nwodo, O.; Sharma, G.; Shah, M. Renewable energy, urbanization, and ecological footprint linkage in CIVETS. Environ. Sci. Pollut. Res. 2020, 27, 19616-19629. [CrossRef]

22. Chen, Z.; Zhou, M. Urbanization and energy intensity: Evidence from the institutional threshold effect. Environ. Sci. Pollut. Res. 2021, 28, 11142-11157. [CrossRef]

23. Günay, M.E. Forecasting annual gross electricity demand by artificial neural networks using predicted values of socio-economic indicators and climatic conditions: Case of Turkey. Energy Policy 2016, 90, 92-101. [CrossRef]

24. Pérez-García, J.; Moral-Carcedo, J. Analysis and long term forecasting of electricity demand trough a decomposition model: A case study for Spain. Energy 2016, 97, 127-143. [CrossRef]

25. Mirasgedis, S.; Sarafidis, Y.; Georgopoulou, E.; Kotroni, V.; Lagouvardos, K.; Lalas, D. Modeling framework for estimating impacts of climate change on electricity demand at regional level: Case of Greece. Energy Convers. Manag. 2007, 48, 1737-1750. [CrossRef]

26. Bianco, V.; Marchitto, A.; Scarpa, F.; Tagliafico, L.A. Forecasting Energy Consumption in the EU Residential Sector. Int. J. Environ. Res. Public Health 2020, 17, 2259. [CrossRef]

27. Khan, M.A. Modelling and forecasting the demand for natural gas in Pakistan. Renew. Sustain. Energy Rev. 2015, 49, 1145-1159. [CrossRef]

28. Wadud, Z.; Dey, H.S.; Kabir, A.; Khan, S.I. Modeling and forecasting natural gas demand in Bangladesh. Energy Policy 2011, 39, 7372-7380. [CrossRef]

29. Azadeh, A.; Asadzadeh, S.; Saberi, M.; Nadimi, V.; Tajvidi, A.; Sheikalishahi, M. A Neuro-fuzzy-stochastic frontier analysis approach for long-term natural gas consumption forecasting and behavior analysis: The cases of Bahrain, Saudi Arabia, Syria, and UAE. Appl. Energy 2011, 88, 3850-3859. [CrossRef]

30. Bianco, V.; Scarpa, F.; Tagliafico, L.A. Analysis and future outlook of natural gas consumption in the Italian residential sector. Energy Convers. Manag. 2014, 87, 754-764. [CrossRef]

31. Rahman, M.M. Exploring the effects of economic growth, population density and international trade on energy consumption and environmental quality in India. Int. J. Energy Sect. Manag. 2020, 14, 1177-1203. [CrossRef]

32. La Greca, P.; Barbarossa, L.; Ignaccolo, M.; Inturri, G.; Martinico, F. The density dilemma. A proposal for introducing smart growth principles in a sprawling settlement within Catania Metropolitan Area. Cities 2011, 28, 527-535. [CrossRef]

33. Ali, W.; Abdullah, A.; Azam, M. The dynamic relationship between structural change and $\mathrm{CO}_{2}$ emissions in Malaysia: A cointegrating approach. Environ. Sci. Pollut. Res. 2017, 24, 12723-12739. [CrossRef]

34. Ali, S.; Razman, M.; Awang, A.; Asyraf, M.; Ishak, M.; Ilyas, R.; Lawrence, R. Critical Determinants of Household Electricity Consumption in a Rapidly Growing City. Sustainability 2021, 13, 4441. [CrossRef]

35. Wang, Q.; Yang, X. Urbanization impact on residential energy consumption in China: The roles of income, urbanization level, and urban density. Environ. Sci. Pollut. Res. 2019, 26, 3542-3555. [CrossRef]

36. Morikawa, M. Population density and efficiency in energy consumption: An empirical analysis of service establishments. Energy Econ. 2012, 34, 1617-1622. [CrossRef]

37. Sarkodie, S.A.; Adom, P.K. Determinants of energy consumption in Kenya: A NIPALS approach. Energy 2018, 159, 696-705. [CrossRef]

38. Li, S.; Shi, J.; Wu, Q. Environmental Kuznets Curve: Empirical Relationship between Energy Consumption and Economic Growth in Upper-Middle-Income Regions of China. Int. J. Environ. Res. Public Health 2020, 17, 6971. [CrossRef] [PubMed]

39. Larivière, I.; Lafrance, G. Modelling the electricity consumption of cities: Effect of urban density. Energy Econ. 1999, 21, 53-66. [CrossRef]

40. Burney, N.A. Socioeconomic development and electricity consumption A cross-country analysis using the random coefficient method. Energy Econ. 1995, 17, 185-195. [CrossRef]

41. Zarco-Soto, I.M.; Zarco-Periñán, P.J.; Sánchez-Durán, R. Influence of climate on energy consumption and $\mathrm{CO}_{2}$ emissions: The case of Spain. Environ. Sci. Pollut. Res. 2020, 27, 15645-15662. [CrossRef]

42. GMES Urban Atlas Project. Mapping Guide for a European Urban Atlas; European Commission: Brussels, Belgium, 2011.

43. Eurostat Methodologies and Working Papers. Statistical Classification of Economic Activities in the European Community; European Commission: Luxembourg, 2008.

44. Instituto Nacional de Estadística-INE. Cifras de Población. Available online: https://www.ine.es/dyngs/INEbase/es/ operacion.htm?c=Estadistica_C\&cid=1254736176951\&menu=ultiDatos\&idp=1254735572981 (accessed on 12 October 2019).

45. Copernicus. Urban Atlas. Available online: https://land.copernicus.eu/local/urban-atlas (accessed on 6 January 2020).

46. Instituto Nacional de Estadística-INE. Demografía y Población. Available online: http: $/ /$ www.ine.es $/$ ss $/$ Satellite?L=es_ES\&c= Page\&cid=1254735910183\&p=1254735910183\&pagename=INE\%2FINELayout (accessed on 1 November 2019).

47. Comisión Nacional de los Mercados y la Competencia. Informe de Supervisión del Mercado de Gas Natural en España; Ministerio de Economía, Industria y Competitividad: Madrid, Spain, 2017.

48. Secretaría de Estado de la Energía. Estadísticas y Balances Energéticos; Ministerio para la Transición Ecológica: Madrid, Spain, 2018. 